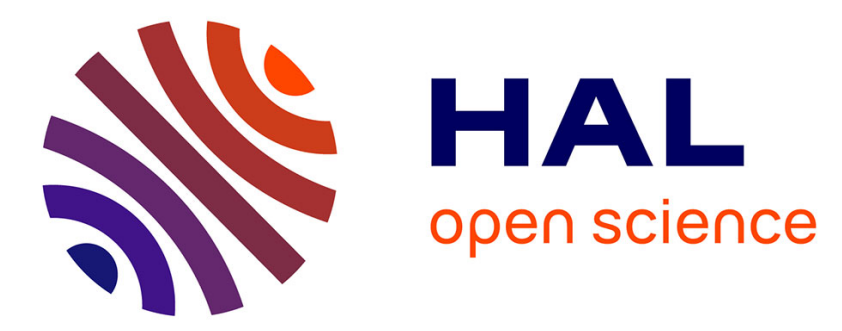

\title{
Literature survey for a first choice of a fuel-oxidiser couple for hybrid propulsion based on kinetic justifications
}

Nicolas Gascoin, Philippe Gillard, Alexandre Mangeot, Ana

Navarro-Rodriguez

\section{To cite this version:}

Nicolas Gascoin, Philippe Gillard, Alexandre Mangeot, Ana Navarro-Rodriguez. Literature survey for a first choice of a fuel-oxidiser couple for hybrid propulsion based on kinetic justifications. Journal of Analytical and Applied Pyrolysis, 2011, doi: 10.1016/j.jaap.2011.11.006. hal-00649391

\section{HAL Id: hal-00649391 https://hal.science/hal-00649391}

Submitted on 7 Dec 2011

HAL is a multi-disciplinary open access archive for the deposit and dissemination of scientific research documents, whether they are published or not. The documents may come from teaching and research institutions in France or abroad, or from public or private research centers.
L'archive ouverte pluridisciplinaire HAL, est destinée au dépôt et à la diffusion de documents scientifiques de niveau recherche, publiés ou non, émanant des établissements d'enseignement et de recherche français ou étrangers, des laboratoires publics ou privés. 
Review

Literature survey for a first choice of a fuel-oxidiser couple for hybrid propulsion based on kinetic justifications.

N. Gascoin ${ }^{\mathrm{a}^{*}}$, P. Gillard ${ }^{\mathrm{a}}$, A. Mangeot ${ }^{\mathrm{a}, \mathrm{b}}$, A. Navarro-Rodriguez ${ }^{\mathrm{a}}$

${ }^{\mathrm{a}}$ University of Orléans

63, avenue de Lattre de Tassigny, 18020 Bourges Cedex, France

${ }^{\mathrm{b}} \mathrm{CNES}$

Rond Point de l'Espace, 91023 Evry Cedex, France

\begin{abstract}
Hybrid rocket propulsion presents an increasing demand because of safety and cost reasons. Numerous works cover the main related areas (regression rate, oxidiser injection, grain design and additives in solid reducer). Nevertheless, the use of detailed kinetic studies, either experimentally or numerically, remains scarce. In particular, the auto-ignition and pyrolysis delays, the nature of chemical species impacting the diffusion flame and the rate of heat release are some of the important parameters. They are rarely considered when choosing a reduceroxidiser couple. Understanding these chemical parameters could help choosing, or later improving, the solid reducers which present low regression speeds (limiting step of hybrid engine due to low combustible gas flow rate). Since detailed chemistry is still a foreign field for hybrid rocket studies, a wide review is first
\end{abstract}

\footnotetext{
* Corresponding author. Tel.: +33.248.238.473; fax: +33.248.238.871. E-mail address: Nicolas.Gascoin@ bourges.univ-orleans.fr (N. Gascoin)
} 
presented to determine how existing chemical works can be of interest for this propulsion technique. Mechanical and thermal characteristics are also considered in addition to combustion ones. Analytical estimation of the requirements to be met by the reducer-oxidiser couple is proposed (combustion heat release and associated heat fluxes, endothermic pyrolysis effect, chemical induction delays). Moreover, the choice of a reducer depends on the operating conditions under which it is used. For this reason, some equilibrium calculations are also provided to investigate the pressure and temperature effects. Among sixteen solid reducers, only three are finally selected in a first step (high density polyethylene -HDPE-, polymethylmethacrylate -PMMA-, hydroxyl terminated polybutadiene -HTPB-). A similar work for oxidisers is conducted among thirteen compounds and three of them are selected (hydrogen peroxide $-\mathrm{H}_{2} \mathrm{O}_{2-}$, nitrous oxide $-\mathrm{N}_{2} \mathrm{O}-$, pure oxygen $\left.\mathrm{O}_{2^{-}}\right)$.

\section{Keywords}

Pyrolysis; Combustion; Hybrid Rocket Propulsion; Solid Fuels; HDPE.

\section{Contents}

Abbreviations and acronyms

1. Introduction

1.1. Hybrid Rocket Propulsion

1.2. Phenomena remaining to be investigated

2. Fuel pyrolysis 
2.1. Limitation of the TGA apparatus for experimental work

2.2. Regression of the reducers under steady state

2.3. Composition of the gaseous pyrolysis products: difference between reducers

3. General observations on combustion with oxidiser

3.1. Initiation of combustion and additives for reducer performance increase

3.2. Potential oxidisers

4. Additional elements impacting the choice of the reducer

4.1. Mechanical and physical characteristics of reducers

4.2. Analytical estimation of heat fluxes and characteristic timescales

4.3. Temperature and pressure effects computed by equilibrium approach

5. Conclusion

Acknowledgements

References

\section{Abbreviations and acronyms}

Isp: specific impulse (s)

TGA: thermogravimetry analysis

AP: ammonium perchlorate $\left(\mathrm{NH}_{4} \mathrm{ClO}_{4}\right)$

GAP: glycidyl azide polymer $\left(\mathrm{CH}_{2}-\right.$

$\left.\mathrm{CH}\left(\mathrm{CH}_{2} \mathrm{~N}_{3}\right)-\mathrm{O}\right)_{\mathrm{n}}$

HAN: hydroxyl ammonium nitrate

$\left(\mathrm{NH}_{3} \mathrm{OH}\right) \mathrm{NO}_{3}$
HDPE: high density polyethylene $\left(\left(\mathrm{CH}_{2}{ }^{-}\right.\right.$ $\left.\left.\mathrm{CH}_{2}\right)_{\mathrm{n}}\right)$

HNF: hydrazinium nitroformate $\left(\mathrm{N}_{2} \mathrm{H}_{5} \mathrm{C}\left(\mathrm{NO}_{2}\right)_{3}\right)$

HTPB: hydroxyl terminated polybutadiene $\mathrm{HO}-\left(\mathrm{C}_{4} \mathrm{H}_{6}\right)_{\mathrm{n}}-\mathrm{OH}$

LDPE: low density polyethylene $\left(\left(\mathrm{CH}_{2}{ }^{-}\right.\right.$ $\left.\left.\mathrm{CH}_{2}\right)_{\mathrm{n}}\right)$ 


\begin{tabular}{|c|c|}
\hline methylmethacrylate & PMMA: polymethylmethacrylate $\left(\mathrm{CH}_{2}-\right.$ \\
\hline $\mathrm{CH}_{2}=\mathrm{C}\left(\mathrm{CH}_{3}\right)\left(\mathrm{COOCH}_{3}\right)$ & $\left.\mathrm{C}\left(\mathrm{CH}_{3}\right)\left(\mathrm{COOCH}_{3}\right)\right)_{\mathrm{n}}$ \\
\hline PA6: polyamide $\left(\mathrm{NH}-\left(\mathrm{CH}_{2}\right)_{5}-\mathrm{CO}\right)_{\mathrm{n}}$ & PP: polypropylene $\left(\mathrm{CH}_{2}-\mathrm{CH}\left(\mathrm{CH}_{3}\right)\right)_{n}$ \\
\hline PC: polycarbonate $\left(\left(\mathrm{CO}-\mathrm{O}-\mathrm{C}_{6} \mathrm{H}_{5}-\mathrm{C}\left(\mathrm{CH}_{3}\right)_{2^{-}}\right.\right.$ & PS: polystyrene $\left(\mathrm{CH}_{2}-\mathrm{CH}\left(\mathrm{C}_{6} \mathrm{H}_{5}\right)\right)_{\mathrm{n}}$ \\
\hline $\left.\left.\mathrm{C}_{6} \mathrm{H}_{5}-\mathrm{O}\right)_{\mathrm{n}}\right)$ & PVA: polyvinyl acetate $\left(\mathrm{CH}_{2}-\mathrm{CH}\left(\mathrm{CH}_{3}-\right.\right.$ \\
\hline PE: polyethylene $\left(\left(\mathrm{CH}_{2}-\mathrm{CH}_{2}\right)_{n}\right)$ & $\mathrm{COO}))_{\mathrm{n}}$ \\
\hline PET: polyethylene terephtalate $\left(\mathrm{CH}_{2}-\mathrm{CH}_{2}-\right.$ & PVC: polyvinyl chloride $\left(\left(\mathrm{CH}_{2}-\mathrm{CHCl}\right)_{\mathrm{n}}\right)$ \\
\hline $\left.\mathrm{O}-\mathrm{CO}-\mathrm{C}_{6} \mathrm{H}_{4}-\mathrm{CO}-\mathrm{O}\right)_{\mathrm{n}}$ & PVDC: polyvinylidene chloride $\left(\left(\mathrm{CH}_{2}-\right.\right.$ \\
\hline & $\left.\left(\mathrm{CCl}_{2}\right)_{\mathrm{n}}\right)$ \\
\hline
\end{tabular}

\section{Introduction}

\subsection{Hybrid Rocket Propulsion}

Aerospace propulsion can be achieved using several technologies depending on the application. The main selection parameters are the specific impulse (Isp) and the thrust, the flight speed, the simplicity of the technology, the storage ability, the safety and the reliability. With the development of space tourism and with the present ecological considerations, the hybrid rocket is one of the emerging propulsion modes [1-3]. This technology involves a solid fuel contained in the combustion chamber and burned with the injected oxidiser, either liquid or gaseous (heterogeneous combustion). The separation of the propellants produces a very safe engine and a potentially flexible solution. By controlling the injection, via a regulation valve, it is possible to adjust the thrust, to shut the engine down and to reignite it later if necessary. Such a technology could also be useful for creating gas generators for safety devices, for example, like car airbags or slide inflators for airplane evacuation. 
At present, numerous solid fuels are being considered, mainly plastic ones such as polyethylene (PE), polypropylene (PP), Polymethyl Methacrylate (PMMA). Polymers are well-known and characterised, easy to handle and to store, and safe under normal conditions. This might even be a way of recycling. The hydroxyl terminated polybutadiene (HTPB) is also largely studied because it is one of the most used in solid propulsion in combination with ammonium perchlorate (AP) as an oxidiser [4]. Other fuels are also presently under investigation because of the current limitations of these solid reducers (low regression rate). Indeed, the addition of metal particles ( $\mathrm{Al}, \mathrm{Li}, \mathrm{Mg}, \mathrm{Be})$ and of metal hydrides $\left(\mathrm{AlH}_{3}\right.$ and others) is investigated [5]. This generally increases the regression rate by about $10 \%$ (due to higher combustion heat release, up to $60 \mathrm{MJ} \mathrm{kg}^{-1}$ ). It can also alter the physical properties of the solid reducer (HTPB is generally used as a binder). Due to the major role of radiation heat transfer, the reducer is often charged in carbon black particles to enhance its heating. However, depending on the mission, the hybrid engine could require a regression rate three times higher than it is presently possible [6]. Consequently, the demand of research on solid reducer is veritably a challenging point. The choice of the oxidiser is more limited, mainly in terms of toxicity and safety. The three most used ones are: oxygen (liquid LOx or gas GOx [7]), hydrogen peroxide $\mathrm{H}_{2} \mathrm{O}_{2}$ [1] and nitrous oxide $\mathrm{N}_{2} \mathrm{O}$ [8]. Due to the large number of available reducers and oxidisers, numerous couples have been tested. Some are still under study today [3]. 


\subsection{Phenomena remaining to be investigated}

If hybrid rocket technology appeared in the 1930s, the first scientific studies aiming at understanding the phenomenon involved were not found before the 1970s [3]. Nowadays, the fundamentals have been acquired and the physical processes of solid regression with pyrolysis and melting, the diffusion and laminar/turbulent flames with the injected oxidiser are well described and are mainly studied numerically $[9,10]$. Nevertheless, these studies do not simultaneously consider the detailed chemistry and physics [11] because of the difficulty of solving transient equations in complex geometry with high velocity reactive flows. Thus, the fluid mechanics is often better described while the chemistry is frequently considered using a one-step Arrhenius law or a thermodynamic approach. For the pyrolysis of the reducer, the regression rate is often tabulated [12]. For the combustion, the global heat release measured during the entire combustion, which is proportional to the maximum instantaneous one, can also be used $[13,14]$. Transient phenomena in combustion, like temperature and pressure oscillations [15,16], could not be observed without pyrolysis kinetics. In comparison with hybrid propulsion, solid propulsion is more widely studied using a detailed kinetic approach [17].

It is absolutely required to consider the detailed chemistry of the pyrolysis to precisely estimate the nature of related products. As a function of their nature, these species will present different diffusion coefficients (considering the detailed approach of multi-component diffusion [18]). This impacts directly the diffusion flame located in the thickness of the boundary layer. The pyrolysis will depend on 
the position of this flame toward the solid surface and along the chamber. This is a coupled phenomenon, driven by chemical process with specific and intrinsic time constant. Chiaverini and Kuo [3], whose book is considered as a reference, present one chapter entitled "Solid-Fuel pyrolysis phenomena and regression rate, part 1; mechanisms". Nevertheless, the mechanisms presented in this chapter refer to global one step schemes, to equilibrium cases and to physical regression of the solid-gas interface. The production of pyrolysis products as a function of time or of operating conditions is not proposed. The same can be concluded for the oxidiser thermal decomposition and for the combustion. This highlights the lack of chemical studies in hybrid technology area.

The section 2 and 3 aim at giving a wide vision of all the phenomena related to the choice of a reducer and of an oxidiser.

\section{Fuel pyrolysis}

Solid fuel pyrolysis happens in two phases. The first one is linked to thermal decomposition in the solid phase with diffusion of light species in the reducer. This is, for example, the case of PMMA (under $773 \mathrm{~K}$ ), and also of the oxidiser AP [17]. This phenomenon depends on the regression rate of the solid [19]. The second phase, controlled by heat and mass transfers [19], is linked to the melting of the solid surface, whose thickness is about few microns. For example, this appears for PMMA over $773 \mathrm{~K}$. So, the pyrolysis results depend on the initial reducer and also on the method of pyrolysis (low or high heating rate). The references which are considered in this paper generally originate from waste and 
recycling purpose. Pyrolysis is also employed as an analysis tool to investigate the chemical formulation of fuels, polymers, composites, ink and rubber. This explains the authors consider restricted operating conditions which do not fit with those of hybrid propulsion. Nevertheless, they can be a good starting point.

\subsection{Limitation of the TGA apparatus for experimental work}

The relative quantities of gas, liquids and solids produced by pyrolysis depend on the mode of decomposition and on the operating conditions (like temperature, heating rate, pressure and residence time). For example, the pyrolysis of PP appears at $700 \mathrm{~K}$ with $2 \mathrm{~K} \mathrm{~min}^{-1}$ and at $780 \mathrm{~K}$ at $50 \mathrm{~K} \mathrm{~min}^{-1}$ [20]. For plastic fuels, more liquid is produced at lower temperatures whereas higher temperatures and longer residence times produce more gas. A pyrolysis temperature within a range of $623 \mathrm{~K}-723 \mathrm{~K}$ is generally the best operating temperature for plastic cracking for recycling purposes in order to obtain valuable liquid petroleum fuels [20]. But this is far from being the range of study for hybrid rocket propulsion, which operates at higher temperatures. In the range of $923 \mathrm{~K}-1123 \mathrm{~K}$, a secondary gas phase cracking occurs and the primary devolatilisation products are cracked resulting in a wide spectrum of smaller hydrocarbons (ranging from $\mathrm{C} 1-$ C9) like alkenes, alkanes, aromatics and gaseous by-products. The high temperature pyrolysis of plastics, which are rich in alkenes, typically produces $65 \%-85 \%$ of gases, $18 \%-22 \%$ of liquid and the rest of soot [21]. However, depending on the pyrolysis conditions, the product composition and concentration can vary [22]. 
TGA (ThermoGravimetric Analysis) allows the kinetic parameters of the one-step Arrhenius law to be easily and rapidly obtained during decomposition in an inert or oxidative atmosphere [23-25]. However, this is not the most appropriate technique because of gradients lower than $50 \mathrm{~K} \mathrm{~s}^{-1}$. In the hybrid rocket, the combustion heat release should be of the order of $10^{7} \mathrm{~K} \mathrm{~s}^{-1}$ [17]. Flash pyrolysis system allows obtaining several thousand degrees per second by pyrolysing a sample deposited within a very thin electrically heated wire. In these conditions, the results differ widely from those obtained by TGA [26]. For example, PMMA flash pyrolysis only shows two compounds; monomer and carbon dioxide [19], while other TGA studies also present $\mathrm{CH}_{4}, \mathrm{CH}_{3} \mathrm{OH}$ and $\mathrm{CO}$ [27]. Consequently, pyrolysis must be studied in appropriate conditions using the appropriate experimental apparatus. The use of a $\mathrm{CO}_{2}$ laser in an inert atmosphere may be a way to get high heating rates to rapidly pyrolyse the surface of the reducer.

\subsection{Regression of the reducers under steady state}

The regression rate is probably the term most widely used to consider reducer pyrolysis [3]. It quantifies the pyrolysis products, through the reducer mass flow rate, which are generated depending on the operating conditions. To estimate the regression rate, the measurements of mass lost during the pyrolysis can be used [28-29]. Other approaches calculate it using the Arrhenius parameters $\left(r=A \cdot e^{-\frac{E_{a}}{R \cdot T}}\right)$ of a one step pyrolysis mechanism; with the pre-exponential factor $A$ expressed in $\mathrm{mm} \mathrm{s}^{-1}$. In solid propulsion, the regression rate of the 
monopropellant is expressed during the combustion by the Vieille or Saint Robert law $r=A . P^{n}$ [30]. Pressure plays a major role on the regression rate because the temperature of combustion mainly depends on the nature of the monopropellant, whereas the pressure is due to the engine design. In hybrid propulsion, the temperature is the most important parameter and it is highly linked to the reducer mass flow rate, through the regression rate.

Table 1 gives a brief overview of the regression rates and the Arrhenius parameter dispersion for some polymers (PMMA, HDPE, PP, HTPB). It must be noticed that the pre-exponential factor is given in $\mathrm{s}^{-1}$ because it refers to the variation of mass fraction of the reducer instead of its thickness as it is generally observed in some numerical modelling. When the Arrhenius law is derived from measures of reducer regression by visualizations or ultra-sonic technique, the preexponential factor is consequently given in $\mathrm{mm} \mathrm{s}^{-1}$ because it is related to the solid-gas interface displacement as a function of time. Considering the density of the reducer, the factor could be expressed in $\mathrm{g} \mathrm{s}^{-1}$. This is also the case when a weight balance is used to estimate the reducer mass loss during the experiment as a function of time. All these units $\left(\mathrm{s}^{-1}, \mathrm{~mm} \mathrm{~s}^{-1}, \mathrm{~g} \mathrm{~s}^{-1}\right.$ and even $\left.\mathrm{g} \mathrm{cm}^{-2} \mathrm{~s}^{-1}\right)$ are consistent and only depend on the need of the user. These data fluctuate considerably in the literature; discrepancies up to several orders of magnitude can be found. For example, the activation energy for PP is $222.3 \mathrm{~kJ} \mathrm{~mol}^{-1}$ in [31] and varies from $250 \mathrm{~kJ} \mathrm{~mol}^{-1}$ to $337 \mathrm{~kJ} \mathrm{~mol}^{-1}$ in [32] and even $373.4 \mathrm{~kJ} \mathrm{~mol}^{-1}$ in [23] (Table 1). This is attributed to the different possible ways of producing the polymer (amorphous or crystallography structures) but also on the method of 
determination because it is known to impact on the result (isoconversional analysis, Kissinger, Freeman-Carroll,...) and of course on the experiments themselves (non isothermal or isothermal conditions, rate of heating). The accuracy of the values given by the original authors varies within the range $1 \%$ $10 \%$ roughly. It can be noted that the number of digits in the activation energies is questionable for such an accuracy range.

In the literature, PMMA (density of $1190 \mathrm{~kg} \mathrm{~m}^{-3}$ ) is found to regress at a rate of $1.8 \mathrm{~g} \mathrm{~cm}^{-2} \mathrm{~s}^{-1}$ while PP (density of $950 \mathrm{~kg} \mathrm{~m}^{-3}$ ) shows a value of $0.8 \mathrm{~g} \mathrm{~cm}^{-2} \mathrm{~s}^{-1}$ [33]. Thanks to the density, these data can be expressed in $\mathrm{mm} \mathrm{s}^{-1}\left(15.12 \mathrm{~mm} \mathrm{~s}^{-1}\right.$ and $8.42 \mathrm{~mm} \mathrm{~s}^{-1}$ respectively) to be compared to Table 1 (less than $1 \mathrm{~mm} \mathrm{~s}^{-1}$ and $0.02 \mathrm{~mm} \mathrm{~s}^{-1}$ respectively). The results are far from comparable.

\section{Table 1 should be placed here}

The regression rate is important from a technological point of view, but it is not uniform inside the combustion chamber due to complex phenomena. For example for PMMA, the rate changes from a factor $2\left(0.2 \mathrm{~g} \mathrm{~s}^{-1}\right.$ to $\left.0.5 \mathrm{~g} \mathrm{~s}^{-1}\right)$ during the ignition due to the temperature [36] (that is to say about $0.42 \mathrm{~mm} \mathrm{~s}^{-1}$ to 1.05 $\mathrm{mm} \mathrm{s}^{-1}$ for a reducer surface around $4 \mathrm{~cm}^{2}$ ). When obtained in "real" conditions, the regression rate depends on other parameters, like the oxidiser flow rate [1], which are not considered or controlled in "lab" conditions. In laboratory, the regression depends on the heating rate, on the heat flux, on the time, on the atmosphere (oxidative or not), on the nature of the polymer samples [37,38] and on its degree of reticulation [39]. Behind these macroscopic parameters, the process of pyrolysis is different from the polymer (end-chain or random initiation) 
because of the chemical bonds which are broken $[19,40,41]$. So, it is important to consider the kinetics of the chemical reactions and not merely a one step mechanism.

\subsection{Composition of the gaseous pyrolysis products: difference between reducers}

The nature of the pyrolysis products acts on the combustion, thus on the engine's thrust, and their compositions differ widely among the initial reducers. The formation of oligomer during plastic pyrolysis depends on the solid polymer [42]. PMMA forms MMA by a depropagation (unzipping) chain reaction (monomer reversion). HDPE produces various hydrocarbons (alkane, alkene, diene) by random scission followed by beta scission (H-abstraction) mechanism $[26,43]$. The same trend as for PMMA is found for Polystyrene (PS) while the Polyvinyl Chloride (PVC) pyrolysis through Side Group Scission [26]. Extended details on polymer pyrolysis can be found in [26]. For flash pyrolysis of PMMA (from $653 \mathrm{~K}$ to $873 \mathrm{~K}$ ), the MMA monomer is the major product (>90\%) and $\mathrm{CO}_{2}$ the second one $[19,27]$. These two compounds are the major ones in their respective phases (liquid and gas). CO is the second gaseous product [44]. The results depend on the test conditions and on the nature of the initial PMMA sample [45]. Such experimental results on PMMA pyrolysis products are also available in [3], as well as for PE and HTPB.

A comparative study (at $30 \mathrm{~K} \mathrm{~min}^{-1}$ ) shows similar trends for plastics pyrolysis (PE, PP, PS) [46]. From $863 \mathrm{~K}$ to $1173 \mathrm{~K}$, the mass amount of tar 
decreases and that of gases increases, except at $1173 \mathrm{~K}$, where the formation of coke is much higher and reduces the part of gases. The gas formation is much more important for PE than for PS (at least a factor 2). For PE, the higher the temperature, the more $\mathrm{H}_{2}$ and $\mathrm{CH}_{4}$ are formed; which is advantageous for combustion purposes. A very similar trend is seen for PE and PP in terms of compounds and concentrations. These concentrations are 2 to 3 times higher than what is observed for PS. For several PS molar masses, and up to $1073 \mathrm{~K}$, styrene is found to be the major pyrolysis product; others are mainly aromatics [31]. This is amplified by temperature. Considering these data, it should be more appropriate to use PE or PP than PS (despite a high density $1050 \mathrm{~kg} \mathrm{~m}^{-3}$ and a high heat release $43 \mathrm{~kJ} \mathrm{~kg}^{-1}$ [47]).

However, two kinds of PE exist depending on the density. LDPE (Low Density PE) produces light alkanes and alkenes mainly at $1173 \mathrm{~K}$, for a residence time of $0.35 \mathrm{~s}$ to $2.5 \mathrm{~s}$. The gas phase represents about $93 \mathrm{wt} \%$ of pyrolysis products with a typical composition of: 4 wt.\%-10 wt.\% $\mathrm{CH}_{4}, 22$ wt.\%-31 wt.\% $\mathrm{C}_{2} \mathrm{H}_{4}, 1.5$ wt.\%-2.7 wt.\% $\mathrm{C}_{2} \mathrm{H}_{6}, 10$ wt.\%-14 wt.\% $\mathrm{C}_{3} \mathrm{H}_{6}, 0.5$ wt.\%-1 wt.\% $\mathrm{C}_{3} \mathrm{H}_{8}$, 4.8 wt.\%-5.6 wt.\% $\mathrm{C}_{4} \mathrm{H}_{8}, 6$ wt.\%-7 wt.\% $\mathrm{C}_{4} \mathrm{H}_{6}$ [21]. Methane increases when the residence time is extended at higher temperature, whereas the fractions of $\mathrm{C}_{3}$ and $\mathrm{C}_{4}$ compounds decrease. $\mathrm{C}_{2} \mathrm{H}_{4}$ and $\mathrm{C}_{2} \mathrm{H}_{6}$ yields are not affected by the residence time. The mono-aromatics are the major compounds in the pyrolysis liquid at high temperature.

The pyrolysis of HDPE shows similar results. At lower temperatures, the main products are solid wax (aliphatic hydrocarbons up to C30) [48] but the 
higher the temperature, the lower the quantity of wax [49]. The gaseous part increases with the temperature up to about $90 \mathrm{wt} \%$ at $1053 \mathrm{~K}$. The oil is composed of aromatics. For both LDPE and HDPE, the proportion between paraffin (alkanes), olefin (alkenes) and aromatics are the same in the liquid or gaseous phases during pyrolysis [50]. The atmosphere also impacts on HDPE pyrolysis and it can yield low polycyclic aromatic hydrocarbons (PAH) concentrations and highly energetic compounds [51]. The choice between HDPE and LDPE cannot be made from a reactive point of view but section 4.1 will provide an answer to this problem.

Other pyrolysis studies are available on plastics (polycarbonate: PC, polyvinyl chloride: PVC, polyvinyl acetate: PVA,...) for recycling purposes [52,53]. The data are more limited than those for PE or PMMA. Due to the toxicity of PVC after combustion, which yields to $\mathrm{HCl}$ formation [54], (in addition to a low heat release of about $15 \mathrm{~kJ} \mathrm{~kg}^{-1}$ [47]) PVC will not be studied here. Despite an interesting exothermic pyrolysis effect, the same safety issue is applicable to GAP due to its nitrogen content [3]. A very long list of other plastic polymers can be drawn, from which the most common are: PA6, PET, ethylenevinyl alcohol co-polymer $\left(\mathrm{CH}_{2}-\mathrm{CH}_{2}\right)_{\mathrm{n}}\left(\mathrm{CH}_{2}-\mathrm{CH}(\mathrm{OH})_{\mathrm{m}}\right.$, $\mathrm{PVC}$ and polyacrilonitrile $\left(\mathrm{CH}_{2}-\mathrm{CH}(\mathrm{CN})\right)_{\mathrm{n}}$. We can notice that PET presents a lower pyrolysis temperature than PE [14]. This may be a good point to allow rapid pyrolysis in the combustion chamber. But due to the lack of studies on PET and on all the others, they will not be considered at present. 
Over $643 \mathrm{~K}$ and up to $883 \mathrm{~K}$, the flash pyrolysis of HTPB is found to be exothermic, while it is endothermic under $643 \mathrm{~K}[15,16]$. The pyrolysis depends on the liquefaction process under $803 \mathrm{~K}$ and on that of desorption over $803 \mathrm{~K}$. A pressure effect is shown, linked to this observation, A sudden change in gaseous products formation is found around $803 \mathrm{~K}$ for low pressure while this disappears for higher pressures. This justifies studying pyrolysis under a wide range of pressures and namely under the expected operating pressure of engines.

In this way, the numerical approach is more convenient than an experimental one. Some numerical schemes are notably available for PE (simplified [32,49,55-57] or detailed [58]) and with one step Arrhenius law or semi detailed mechanisms for halogenated polymer [54], for PET [59], PS [31,60] , PP [60], HTPB [15,16]. In the formation of a simplified scheme, the Arrhenius parameters are necessary for the consumption of initial polymer, for example HTPB [61], but also for the formation of pyrolysis products. A maximum of six major gaseous products has been found for HTPB detailed kinetic pyrolysis (Butadiene, 4-vinyl-l-cyclohexene, trans-butadiene oligomers, ethylene, 1,5 hexadiene and cyclopentene) $[15,16]$.

\section{General observations on combustion with oxidiser}

The pyrolysis of the reducer is not only dependent on the temperature or on the residence time. It is a coupled process with the combustion since this latest provides the heat flux for the pyrolysis. The oxidative atmosphere can play a role in the degradation process. The injection of the oxidiser physically impacts on the 
solid fuel regression rate [62]. The axial injector provides a higher regression rate, stability and combustion efficiency compared to the radial injector. This is due to the residence time and to the turbulence [63]. The oxidiser injection also modifies the oxidiser mass flow rate, that is to say the Oxidiser/Fuel ratio. The ignition time is clearly dependent on this point [11]. However, the oxidiser concentration no longer seems to impact on the pyrolysis over a certain value [33] and the phenomena are mainly piloted by the fluid flow. So, the reducer should present a pyrolysis rate in good agreement with the oxidiser mass flow rate. A linear relationship exists between these two parameters $[1,36]$ and also between the burning and pyrolysis rates [64].

\subsection{Initiation of combustion and additives for reducer performance increase}

The ignition method can impact on the choice of the reducer. For a given technique, firstly a sufficient quantity of gases is required to be produced, in relation with the oxidiser mass flow rate. This is linked to intrinsic parameters, for example the pyrolysis temperature and the decomposition rate, the thermal diffusivity and the infrared absorption of the reducer. Some new methods, such as the $\mathrm{CO}_{2}$ laser techniques $[65,66]$, may be useful for hybrid combustion chamber because they can reignite the engine after shutting it down during the flight.

Considering the potential of fuels, the addition of metallic compounds is a way to increase their combustive and thermo-mechanical properties (increase of regression rate notably), such as the flame temperature and the density. Using additives with exothermic decomposition will be a benefit [1]. If these additives 
are oxidant (such as in solid monopropellant), there is a higher benefit in terms of specific impulse (twice more). With metals, the benefit increases by $30 \%$ [1]. Among these additives, alane $\left(\mathrm{AlH}_{3}\right)$ seems promising because it increases the Isp and reduces the throat erosion $[67,68]$. Other types of fuels are considered, such as silane $\left(\mathrm{Si}_{\mathrm{n}} \mathrm{H}_{\mathrm{n}+2}\right)$, because they present higher specific impulse [69]. Nevertheless, no additives will be considered in the present study because they require specific and dedicated work. Some works related to thermodynamic calculations on additives could be mentioned [70] and very rare consider simplified kinetic mechanism [71]. Furthermore, the additives increase the combustion temperature but they do not participate to the thrust because they do not generate directly gas formation, which would increase the momentum quantity. This explains why additives remain limited.

\subsection{Potential oxidisers}

The oxidisers should be non toxic, safe and present a high burning rate and burning velocity. For toxicity reasons, $\mathrm{N}_{2} \mathrm{O}_{4}$ is not studied, despite its high energetic performances. This also goes for other nitro compounds and for several fluoro compounds $\left(\mathrm{BrF}_{5}, \mathrm{ClF}_{3}, \mathrm{ClO}_{3} \mathrm{~F}\right)$, even diluted in oxygen. Hydrazinium NitroFormate (HNF) shows a higher heat release during the thermal decomposition than Hydroxyl Ammonium Nitrate (HAN) [72]. They both have a great Isp and density. HAN and HNF are found in mixtures with water, which is undesirable for propulsion applications. HAN, HNF and AP are not considered because of their environment unfriendliness. 
Pure oxygen is important to consider. It is the reference used to compare the other oxidiser capacities. But no oxygen based solution will be proposed in this paper due to the storage and handling difficulties of cryogenic liquid oxygen. The gaseous oxygen is not interesting because it has poor density.

$\mathrm{H}_{2} \mathrm{O}_{2}$ can dissociate spontaneously owing to the temperature. That makes it dangerous because it behaves like a monopropellant. The walls of the tank must be passivated to avoid catalysis effects. Furthermore, it is combined with water (generally 2 vol.\% to 15 vol.\%) to limit this effect, but the water is a final combustion product and is undesirable for combustion purposes. Nevertheless, these technological problems may be corrected in the future by additives or by mixing $\mathrm{H}_{2} \mathrm{O}_{2}$ it with other products, thanks to its high miscibility.

$\mathrm{N}_{2} \mathrm{O}$ is more interesting than $\mathrm{NO}$ or $\mathrm{NO}_{2}$ in terms of toxicity and energetic performance. It is considered to be relatively safe and non toxic (even used for medical purposes in hospitals). It has a high density $\left(1980 \mathrm{~kg} \mathrm{~m}^{-3}\right.$ when stored at liquid conditions around 35 bar). $\mathrm{N}_{2} \mathrm{O}$ could be studied as a monopropellant thanks to a catalyser [8] $\left(\mathrm{H}_{2} \mathrm{O}_{2}\right.$ [73], $\mathrm{HAN}$ and $\mathrm{HNF}$ also [72]). The specific impulse is, for example, expected to be $210 \mathrm{~s}$ at $1873 \mathrm{~K}$ [8].

When comparing the above polymers in terms of steady-state parameters like the specific impulse, all of them present approximately the same behavior [3]. For example, combustion with $\mathrm{N}_{2} \mathrm{O}$ gives an Isp of $247 \mathrm{~s}$ for HTPB and PE, $248 \mathrm{~s}$ for Paraffin and $252 \mathrm{~s}$ with addition of $40 \mathrm{wt} . \% \mathrm{Al}$. This is also noted for $\mathrm{LO}_{\mathrm{x}}$. But when regarding the burning rates; that of $\mathrm{O}_{2}$ is higher than that of $\mathrm{H}_{2} \mathrm{O}_{2}$ because of the higher combustion temperature and higher combustion efficiency [1]. This 
efficiency is linked to the limited mixing of the reducer and oxidiser [1]. Thus, a deeper kinetic study needs to be conducted numerically [74].

\section{Additional elements impacting the choice of the reducer}

In conclusion to sections 2 and 3 , the reducers that present the most interesting properties are HDPE, PMMA and HTPB (due to the nature of pyrolysis gas products and to their solid properties in addition to safety, cost, toxicity and performance point of view). They will be numerically studied in a companion paper [74] in order to help in selecting one of them with the appropriate oxidiser (among $\mathrm{H}_{2} \mathrm{O}_{2}, \mathrm{~N}_{2} \mathrm{O}$ and $\mathrm{O}_{2}$ ).

\subsection{Mechanical and physical characteristics of reducers}

Reducers also need to be studied with respect to their thermo-mechanical properties. Apart from the reactivity aspects, the characteristics of solid fuels should be considered to ensure they can withstand the high heat load due to the combustion. This kind of consideration is found for gels dedicated to other propulsion techniques [75] but still remains absent for the hybrid rocket. For the thermal resistance, the melting temperature and the thermal conductivity are the most important data. On the basis of the preceding sections, a selection of polymers is observed (Table 2). Only the products without toxicity issues are considered. The LDPE is not given specifically but most of the data can be found for PE independently from its structure (LDPE or HDPE) because the difference is mainly related to the density and not to the reactivity. A direct link exists 
between the gasification of solid fuels and their transformation heat [1]. It is preferable to consider solid fuels with low heat capacity and melting latent heat [1]. However, with higher heat capacity, the thermal diffusivity will be lower and the consistency of the reducer is more easily ensured.

\section{Table 2 should be placed here}

For comparable reactive behaviours, HDPE $\left(960 \mathrm{~kg} \mathrm{~m}^{-3}\right)$ is preferable to LDPE $\left(920 \mathrm{~kg} \mathrm{~m}^{-3}\right)$ and to PP $\left(950 \mathrm{~kg} \mathrm{~m}^{-3}\right)$. PC is no longer considered due to its low heat release in comparison to HDPE notably and because no numerical pyrolysis scheme has been found. In regards, PMMA is still considered despite a lower heat release because it is more widely studied. More available data can be found to serve as a basis and to go further. HTPB also presents a low heat release but it is commonly used with additives to overcome this drawback. Thus, HTPB will be studied in this paper and in [74], but alone without other compounds in addition. The elastic modulus is relatively comparable between the compounds considered except for that of HTPB, which is very low. Despite this, HTPB is commonly used in solid propulsion and there is not a problem in maintaining the mechanical characteristics.

The maximum temperature that can be sustained by polymers in continuous operating conditions is not considered because it is rapidly exceeded due to the combustion. The cost is not a parameter of choice because these polymers are common enough not to present economic issues. The question of storage ability should, nevertheless, be taken into account. It is well-known that polymers can be altered with time, due to the thermal conditions for example. Aged plastics can 
thus pyrolyse at lower temperatures than new ones $[42,78]$. But this point needs a specific study and the available data in the literature are very sparse. The porosity of solids may also be considered because of its involvement in the chemical process. It also impacts on the thermal and mechanical characteristics.

\subsection{Analytical estimation of heat fluxes and characteristic timescales}

This section aims at fixing the order of heat fluxes (heating, phase change, pyrolysis and combustion by radiative, conductive and convective transfers) and of timescales (fluid mechanics, heat transfer, pyrolysis time, combustion time) that are expected in the hybrid combustor. They enable to judge if the pyrolysis/combustion times (sections 2 and 3) are suitable for hybrid propulsion.

For a typical residence time of $20 \mathrm{~ms}$ [3], the reducer must be heated and pyrolysed, as must the oxidiser if applicable. HDPE is chosen in this section by way of example. The combustion must also be initiated and finished.

If $85 \% \mathrm{H}_{2} \mathrm{O}_{2}$ mixture is used, for example, it will decompose in $2 \mathrm{~ms}$ at $2229 \mathrm{~K}$ [74]. To get a stoichiometric combustion with $1 \mathrm{~m}^{2}$ of HDPE, a $\mathrm{H}_{2} \mathrm{O}_{2}$ mass flow rate of $6.76 \mathrm{~kg} \mathrm{~s}^{-1}$ is necessary. This corresponds to an exothermic decomposition flux of $16.22 \mathrm{MW} \mathrm{m}^{-2}$ [74]. However, to heat the $\mathrm{H}_{2} \mathrm{O}_{2}$ from $300 \mathrm{~K}$

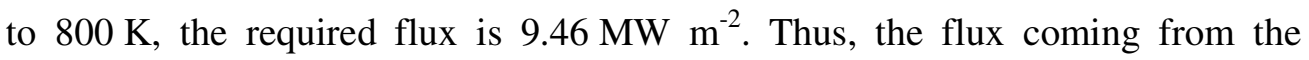
exothermic oxidiser decomposition is $6.76 \mathrm{MW} \mathrm{m}^{-2}$. By burning $1 \mathrm{~mm} \mathrm{~s}^{-1}$ of HDPE, the heat released is $40.3 \mathrm{MW} \mathrm{m}^{-2}$. Consequently, the overall heat flux generated in the combustion chamber is $47.06 \mathrm{MW} \mathrm{m}^{-2}$. The radiative and convective heat fluxes of the flame toward the solid reducer are respectively 
7.5 $\mathrm{MW} \mathrm{m}^{-2}$ and $1.13 \mathrm{MW} \mathrm{m}^{-2}$. The other part of the incoming heat flux (about 38.43 $\mathrm{MW} \mathrm{m}^{-2}$ ) remains in burned gases to participate in the thrust.

For a pyrolysis time of $1 \mathrm{~ms}[3,74]$, the reducer must be heated up to $1250 \mathrm{~K}$ [74]. To increase the solid temperature from $300 \mathrm{~K}$ to the melting temperature of $415 \mathrm{~K}\left(204 \mathrm{~kW} \mathrm{~m}^{-2}\right)$, the time required is about $2 \mathrm{~ms}$. With a fusion enthalpy of $1940 \mathrm{~J} \mathrm{~kg}^{-1}$ (with $2000 \mathrm{~g} \mathrm{~mol}^{-1}$ ) for HDPE, the heat absorbed for the phase change during this time is $931.2 \mathrm{~kW} \mathrm{~m}^{-2}$. Considering an endothermic effect of $5 \mathrm{MJ} \mathrm{kg}^{-1}$, the heat flux required for the pyrolysis is 4.8 $\mathrm{MW} \mathrm{m} \mathrm{m}^{-2}$. Heating the pyrolysis products to $1250 \mathrm{~K}$, with the same time order, requires a heat flux of $1.5 \mathrm{MW} \mathrm{m} \mathrm{m}^{-2}$. Finally, the heat flux dedicated to the reducer is $7.44 \mathrm{MW} \mathrm{m}^{-2}$. A part of the incoming heat flux is conducted through the solid. The conductive flux is $380 \mathrm{~kW} \mathrm{~m}^{-2}$ to increase the solid temperature from $300 \mathrm{~K}$ to $1250 \mathrm{~K}$ by conduction over $1 \mathrm{~mm}$. The associated time, $4.6 \mathrm{~ms}$, is lower than that of the regression. Thus, the conduction in the solid is not a limiting step.

To conclude, all the heat fluxes computed above are compatible with the hybrid chamber. The choice between the reducer and the oxidiser will not be made on the basis of heat flux, but mainly on the characteristic times (pyrolysis time and ignition time). By adding all the times from this section, a total of $8 \mathrm{~ms}$ is found. This is acceptable because the residence time in the combustor is $20 \mathrm{~ms}$.

\subsection{Temperature and pressure effects computed by equilibrium approach}

The HSC Chemistry software [79] has been used in a first step to conduct thermodynamic equilibrium on a wide temperature and pressure range (323 $\mathrm{K}$ to 
$2273 \mathrm{~K}$ and 1 bar to 100 bar) for comparison with kinetic computations. HTPB and PMMA are considered numerically.

For HTPB, a sensitivity study has been conducted to ensure the right representation of decomposition phenomena. Twenty-two compounds are considered as final decomposition products to compute their formation during HTPB pyrolysis $\left(\mathrm{CH}_{4}, \mathrm{C}_{2} \mathrm{H}_{2}, \mathrm{C}_{2} \mathrm{H}_{4}, \mathrm{C}_{3} \mathrm{H}_{6}, \mathrm{C}_{4} \mathrm{H}_{6}, \mathrm{C}_{4} \mathrm{H}_{8}, \mathrm{C}_{5} \mathrm{H}_{8}, \mathrm{C}_{6} \mathrm{H}_{6}, \mathrm{C}_{6} \mathrm{H}_{8}, \mathrm{C}_{6} \mathrm{H}_{10}\right.$, $\mathrm{C}_{7} \mathrm{H}_{8}, \mathrm{C}_{8} \mathrm{H}_{12}, \mathrm{C}_{8} \mathrm{H}_{14}, \mathrm{C}_{12} \mathrm{H}_{14}, \mathrm{C}_{16} \mathrm{H}_{26}, \mathrm{H}_{2}, \mathrm{O}_{2}, \mathrm{CO}, \mathrm{CO}_{2}, \mathrm{CH}_{2} \mathrm{O}, \mathrm{C}_{2} \mathrm{H}_{6} \mathrm{O}$, solid $\mathrm{C}$ ). This list has been established on the basis of open literature $[3,15,61]$. Water or methanol are not considered due to their negligible formation, even as products of secondary decomposition mechanism. Furthermore, water could be artificially observed by equilibrium computation. It is better to not consider it than largely over-estimating it.

With HSC, solid carbon and methane are the major decomposition products under $750 \mathrm{~K}$ while hydrogen and solid carbon are the major products above $750 \mathrm{~K}$. A $\mathrm{CO}$ and $\mathrm{CO}_{2}$ formation is observed. But the composition of pyrolysis products is different from the literature data, which are obtained experimentally [3]. No $\mathrm{C}_{4} \mathrm{H}_{6}$ or $\mathrm{C}_{8} \mathrm{H}_{12}$ are found around $773 \mathrm{~K}$ contrary to [3]. Products with a molar mass of between those of $\mathrm{C}_{2} \mathrm{H}_{4}$ and $\mathrm{C}_{7} \mathrm{H}_{8}$ should be found around $1073 \mathrm{~K}$ while none is observed numerically. This is due to the thermodynamic approach, which considers an infinite time during which these compounds are unstable. The experimental data are generally obtained at atmospheric pressure, for medium residence time (less than an hour) and "low" temperature (under $1000 \mathrm{~K}$ ). Both 
equilibrium and experimental conditions are incompatible with those of hybrid technology.

But the pressure effect can be investigated properly by thermodynamic calculations (Figure 1). The higher the temperature (from Figure 1a to Figure 1d), the higher this pressure effect. It is also more interesting to have a high operating temperature because of $\mathrm{C}_{2} \mathrm{H}_{2}$ and $\mathrm{H}_{2}$ formation at $2000 \mathrm{~K}$ replacing the $\mathrm{CH}_{4}$, which is in majority up to $1500 \mathrm{~K}$. At around 70 bar, $\mathrm{C}_{2} \mathrm{H}_{2}$ reaches a maximum concentration. This seems to be the optimum operating pressure. This is interesting because the thrust is linked to the internal pressure.

\section{Figure 1 should be placed here}

The same thermodynamic approach has been used for PMMA (chemical formula: $\left.\left(\mathrm{C}_{5} \mathrm{H}_{8} \mathrm{O}_{2}\right)_{n}\right)$. After a sensitivity analysis, 26 pyrolysis products are retained, in gas, liquid and solid phases $\left(\mathrm{H}_{2}, \mathrm{CH}_{4}, \mathrm{C}_{2} \mathrm{H}_{4}, \mathrm{C}_{2} \mathrm{H}_{6}, \mathrm{C}_{3} \mathrm{H}_{6}, \mathrm{C}_{3} \mathrm{H}_{8}, \mathrm{C}_{4} \mathrm{H}_{6}\right.$, $\mathrm{C}_{4} \mathrm{H}_{8}, \mathrm{C}_{4} \mathrm{H}_{10}, \mathrm{C}_{5} \mathrm{H}_{8}, \mathrm{C}_{5} \mathrm{H}_{10}, \mathrm{CH}_{3} \mathrm{OH}, \mathrm{C}_{6} \mathrm{H}_{6} \mathrm{O}, \mathrm{CO}, \mathrm{CO}_{2}, \mathrm{H}_{2} \mathrm{O}$ (gas and liquid), $\mathrm{C}_{3} \mathrm{H}_{6} \mathrm{O}, \mathrm{C}_{4} \mathrm{H}_{6} \mathrm{O}_{2}, \mathrm{C}_{4} \mathrm{H}_{8} \mathrm{O}_{2}, \mathrm{C}_{5} \mathrm{H}_{8} \mathrm{O}_{2}, \mathrm{C}_{5} \mathrm{H}_{10} \mathrm{O}_{2}, \mathrm{C}_{5} \mathrm{H}_{12} \mathrm{O}, \mathrm{C}_{6} \mathrm{H}_{6} \mathrm{O}, \mathrm{C}_{6} \mathrm{H}_{12} \mathrm{O}_{2}$, solid C). Comparing to literature at around $800 \mathrm{~K}$ [80-82], $\mathrm{H}_{2}, \mathrm{CH}_{4}, \mathrm{CO}$, and $\mathrm{CO}_{2}$ (Figure 2) are found in similar proportions but no ethylene, propylene or methanol are found. The pressure highly impacts the pyrolysis products' formation, even at $500 \mathrm{~K}$ contrary to what is observed for HTPB. Over $1500 \mathrm{~K}$, low pressure (lower than 20 bar) gives high hydrogen content; which is interesting for combustion purposes.

Figure 2 should be placed here 


\section{Conclusion}

Hybrid propulsion is a promising technology from an ecological point of view, as well as considering its simplicity and flexibility. The related phenomena are widely studied except the chemical kinetics for which a strong lack of dedicated work appears. The detailed chemistry enables to transiently estimate the flow rate and the nature of gaseous pyrolysis products. Their combustion must also be studied since it generates the heat flux to pyrolyse the solid fuel. This coupling depends directly on the chemical nature of species (diffusion flame), which drives the phenomena involved in hybrid engine. The time constants induced by the chemistry must be considered and are part of the choice of a reducer-oxidiser couple. Instead of choosing a reducer on the basis of the quantity of gas it can produce (regression rate), the quality of the gas compounds (autoignition delay, combustion efficiency, physical properties such as diffusion coefficient and heat capacity) and the way they are produced (chemical induction delay) are at least as important. The solid properties have to be considered since the reducer must meet some criterion in addition to burning capacities.

Through a large review of literature on the chemical behaviour and thermomechanical properties of polymers, three reducers (PMMA, HDPE, HTPB) have been selected to be numerically studied in a companion paper [74]. Three oxidisers $\left(\mathrm{H}_{2} \mathrm{O}_{2}, \mathrm{~N}_{2} \mathrm{O}\right.$ and $\left.\mathrm{O}_{2}\right)$ have also been selected for related combustion study. Large variations in Arrhenius parameters, in regression rates and in pyrolysis products composition have been found because of operating conditions of study, of the crystallography structure and of the purity of the samples. This 
highlights the difficulty to get reference data for hybrid propulsion purpose. The heat fluxes and the timescales of all the phenomena encountered in hybrid combustion chamber have been estimated analytically. A total time of $8 \mathrm{~ms}$ has been estimated for the heat transfers and the chemistry to get completed. The pressure effect on the pyrolysis is shown through equilibrium computations and it increases with the temperature. Ethylene, acetylene and methane are favoured by high pressures. Optimum working temperature of $2000 \mathrm{~K}$ and pressure of 70 bar appear for HTPB (1500 K and 20 bar respectively for PMMA). These values must be compared to those from kinetic study [74]. The effect of the time and the composition of products must be investigated since several optimums could exist.

\section{Acknowledgements}

The authors would like to acknowledge the Roxel company and the CNES for their support since the present work has been achieved.

\section{References}

[1] N.A. Davydenko, R.G.Gollender, A.M. Gubertov, V.V. Mironov, N.N. Volkov, Hybrid rocket engines: The benefits and prospects, Aerosp. Sci. Technol. 11 (2007) 55-60.

[2] D. Stone, A. Lindenmoyer, G. French, E. Musk, D. Gump, C.Kathuria, C. Miller, M. Sirangelo, T. Pickens, NASA's approach to commercial cargo and crewtransportation, Acta Astronaut. 63 (2008) 192-197. 
[3] M.J. Chiaverini, K.K. Kuo, Fundamentals of Hybrid Rocket Combustion and Propulsion, Progress in Astronautics and Aeronautics, AIAA 218, 2007.

[4] T.P. Parr, D.M. Hanson-Parr, M.D. Smooke, R.A. Yetter, AP/(N2 + C2H2 + C2H4) gaseous fuel diffusion flame studies, P. Combust. Inst. 30 (2005) $2113-2121$.

[5] L.T. DeLuca, C. Paravan, A. Reina, E. Marchesi, B.M. Kosowski, Aggregation and Incipient Agglomeration in Metallized Solid Propellants and Solid Fuels for Rocket Propulsion, in: 46th AIAA/ASME/SAE/ASEE Joint Propulsion Conference \& Exhibit, Nashville, Tennessee, July 25-28, 2010, AIAA-2010-6752.

[6] F. Martin, A. Chapelle, O. Orlandi, P. Yvart, Hybrid propulsion systems for future space applications, in: $46^{\text {th }}$ AIAA/ASME/SAE/ASEE Joint Propulsion Conference \& Exhibit, Nashville, Tennessee, July 25-28, 2010, AIAA-20106633.

[7] R. D. Swami and A. Gany, Analysis and testing of similarity and scale effects in hybrid rocket motors, Acta Astronaut. 52 (2003) 619-628.

[8] V. Zakirov and H.-Y. Zhang, A model for the operation of nitrous oxide monopropellant, Aerosp. Sci. Technol. 12 (June (4)) (2008) 317-323.

[9] G. Zheng, I. S. Wichman, A. Bénard, Opposed-Flow Flame Spread Over Polymeric Materials: Influence of Phase Change, Combust. Flame 124 (2001) 387-408.

[10] C.Y. Han, Radiative combustion of pyrolyzing fuel in a cylindrical combustor, Fuel 83 (2004) 343-351. 
[11] Y.Y. Zhou, D.C. Walther, A. C. Fernandez-Pello, Numerical Analysis of Piloted Ignition of Polymeric Materials, Combust. Flame 131 (2002) 147158.

[12] P. J. Coelho, N. Duic, C. Lemos, M.G. Carvalho, Modelling of a Solid Fuel Combustion Chamber of a Ramjet Using a Multi-block Domain Decomposition Technique, Aerosp. Sci. Technol. 2 (1998) 107-119.

[13] Y. Pizzo, J.L. Consalvi, P. Querre, M. Coutin, B. Porterie, Width effects on the early stage of upward flame spread over PMMA slabs: Experimental observations, Fire Safety J. 44 (April (3)) (2009) 407-414.

[14] A.P. Mouritz, Z. Mathys, A.G. Gibson, Heat release of polymer composites in fire, Compos. Part. A-Appl. S. 37 (2006) 1040-1054.

[15] H. Arisawa and T.B. Brill, Flash Pyrolysis of Hydroxyl-Terminated Polybutadiene (HTPB) I: Analysis and Implications of the Gaseous Products, Combust. Flame 106 (1996) 131-143.

[16] H. Arisawa and T.B. Brill, Flash Pyrolysis of Hydroxyl-Terminated Polybutadiene (HTPB) II: Implications of the Kinetic to Combustion of Organic Polymers, Combust. Flame 106 (1996) 144-154.

[17] M.W. Beckstead, Recent Progress in Modeling Solid Propellant Combustion, Combust. Explo. Shock+ 42 (6) (2006) 623-641.

[18] B.V. Lidskii, M.G. Neuhaus, V.Y. Basevich, S.M. Frolov, Multicomponent diffusion in laminar flames, Chimitseskaia Physika 22 (3) (2003) 51-60.

[19] H. Arisawa and T.B. Brill, Kinetic and Mechanisms of Flash Pyrolysis of Poly, methyl methacrylate, (PMMA), Combust. Flame 109 (1997) 415-426. 
[20] A. Aboulkas, K. El Harfi, A. El Bouadili, Non-isothermal kinetic studies on co-processing of olive residue and polypropylene, Energ. Convers. Manage. 49 (2008) 3666-3671.

[21] S.F. Sodero, F. Berruti, L.A. Behie, Ultrapyrolytic Cracking of Polyethylene-A High Yield Recycling Method, Chem. Eng. Sci. 51 (June (11)) (1996) 2805-2810.

[22] C. Di Blasi, Transition between regimes in the degradation of thermoplastic Polymers, Polym. Degrad. Stabil. 64 (1999) 359-367.

[23] P. Grammelis, P. Basinas, A. Malliopoulou, G. Sakellaropoulos, Pyrolysis kinetic and combustion characteristics of waste recovered fuels, Fuel 88 (2009) 195-205.

[24] D.M. Bate and R.S. Lehrle, Kinetic measurements by pyrolysis-gas chromatography and examples of their use in deducing mechanisms, Polym. Degrad. Stabil. 53 (1996) 39-44.

[25] D.M. Bate, R.S. Lehrle, C.S. Pattenden, E.J. Place, A critical comparison of procedures for evaluating rate constants in thermal degradation, illustrated by pyrolysis-G.C. results from four polymers, Polym. Degrad. Stabil. 62 (1998) 73-83.

[26] T. Wampler, Applied Pyrolysis Handbook, second Ed. CRC Press, 2007.

[27] K. Smolders and J. Baeyens, Thermal degradation of PMMA in fluidised beds, Waste Manage. 24 (2004) 849-857.

[28] U. Hujuri, A.K. Ghoshal, S. Gumma, Modeling pyrolysis kinetic of plastic mixtures, Polym. Degrad. Stabil. 93 (2008) 1832-1837. 
[29] L. Ballice and R. Reimert, Classification of volatile products from the temperature-programmed pyrolysis of polypropylene (PP), atacticpolypropylene (APP) and thermogravimetrically derived kinetic of pyrolysis, Chem. Eng. Process. 41 (2002) 289-296.

[30] A. Van Tiggelen, Oxydations et combustions. Tome 2, pp 704. ISBN 27108-0093-4, 1968.

[31] T. Faravelli, M. Pinciroli, F. Pisano, G. Bozzano, M. Dente, E. Ranzi, Thermal degradation of polystyrene, J. Anal. Appl. Pyrol. 60 (June (1)) (2001) 103-121.

[32] C. David, S. Salvador, J.L. Dirion, M. Quintard, Determination of a reaction scheme for cardboard thermal degradation using thermal gravimetric analysis, J. Anal. Appl. Pyrol. 67 (May (2)) (2003) 307-323.

[33] D. Rich, C. Lautenberger, J. L. Torero, J.G. Quintiere, C. Fernandez-Pello, Mass flux of combustible solids at piloted ignition, P. Combust. Inst. 31 (2007) 2653-2660.

[34] A. Ishiharaa, Y. Sakaia, K. Konishia, E. Andoh, Correlation between burning surface temperature and regression rate for polymethylmethacrylate, P. Combust. Inst. 30 (2005) 2123-2130.

[35] United States Nuclear Regulatory Commission, Chapter 3. Estimating Burning Characteristics Of Liquid Pool Fire, Heat Release Rate, Burning Duration, And Flame Height, Fire Dynamics Tools, FDTs, Quantitative Fire Hazard Analysis Methods for the U.S. Nuclear Regulatory Commission Fire Protection Inspection Program, NUREG-1805, Final Report. 
[36] Y. Pizzo, Caractérisation de la flamme de diffusion établie le long d'un combustible solide en convection naturelle par le nombre de transfert de masse, Ph.D. Thesis, Provence University, 28/11/2007.

[37] M. Ferriol, A. Gentilhomme, M. Cochez, N. Oget, J.L. Mieloszynski, Thermal degradation of polymethyl methacrylate, PMMA: modelling of DTG and TG curves, Polym. Degrad. Stabil. 79 (2003) 271-281.

[38] B. Zhang and F.D. Blum, Thermogravimetric study of ultrathin PMMA films on silica: effect of tacticity, Thermochim. Acta 396 (2003) 211-217.

[39] S.S. Panicker, K.N. Ninan, Influence of molecular weight on the thermal decomposition of hydroxyl terminated polybutadiene, Thermochim. Acta 290 (1997) 191-197.

[40] B.J. Holland and J.N. Hay, The kinetic and mechanisms of the thermal degradation of poly, methyl methacrylate, studied by thermal analysisFourier transform infrared spectroscopy, Polymer 42 (2001) 4825-4835.

[41] K. Smolders and J. Baeyens, Thermal degradation of PMMA in fluidised beds, Waste Manage. 24 (2004) 849-857.

[42] H.H.G. Jellinek, Aspects of Degradation and Stabilization of Polymers, Elsevier, ISBN 0-444-41563-7.

[43] R.S. Lehrle, D. J. Atkinson, D.M. Bate, P.A. Gardner, M.R. Grimbley, S.A. Groves, E.J. Place, R.J. Williams, Diagnosing mechanisms of oligomer formation in the thermal degradation of polymers, Polym. Degrad. Stabil. 52 (1996) 183-196. 
[44] W. Kaminsky and C. Eger, Pyrolysis of filled PMMA for monomer Recovery, J. Anal. Appl. Pyrol. 58-59 (2001) 781-787.

[45] B.J. Holland and J.N. Hay, The effect of polymerisation conditions on the kinetic and mechanisms of thermal degradation of PMMA, Polym. Degrad. Stabil. 77 (2002) 435-439.

[46] Y. Ohmukai, I. Hasegawa, K. Mae, Pyrolysis of the mixture of biomass and plastics in countercurrent flow reactor Part I: Experimental analysis and modeling of kinetic, Fuel 87 (October (13-14)) (2008) 3105-3111.

[47] C. Vovelle and J.L. Delfeau, Combustion des Plastiques, Techniques de l'Ingénieur, July 1997, AM3170.

[48] F.J. Mastral, E. Esperanza, P. Garcia, M. Juste, Pyrolysis of high-density polyethylene in a fluidised bed reactor. Influence of the temperature and residence time, J. Anal. Appl. Pyrol. 63 (March (1)) (2002) 1-15.

[49] G. Elordi, G. Lopez, M. Olazar, R. Aguado, J. Bilbao, Product distribution modelling in the thermal pyrolysis of high density polyethylene, J. Hazard. Mater. 144 (2007) 708-714.

[50] A. Marcilla, M.I. Beltran, R. Navarro, Thermal and catalytic pyrolysis of polyethylene over HZSM5 and HUSY zeolites in a batch reactor under dynamic conditions, Appl. Catal. B-Environ. 86 (1-2) (2009) 78-86.

[51] F.J. Mastral, E. Esperanza, C. Berrueco, M. Juste, J. Ceamanos, Fluidized bed thermal degradation products of HDPE in an inert atmosphere and in air-nitrogen mixtures, J. Anal. Appl. Pyrol. 70 (2003) 1-17. 
[52] T. Uyar, A.E. Tonelli, J. Hacaloglu, Thermal degradation of polycarbonate, poly, vinyl acetate, and their blends, Polym. Degrad. Stabil. 91 (2006) 29602967.

[53] Z. Ahmad, N.A. Al-Awadi, F. Al-Sagheer, Thermal degradation studies in poly, vinyl chloride,/poly, methyl methacrylate, blends, Polym. Degrad. Stabil. 93 (2008) 456-465.

[54] M. Mehl, A. Marongiu, T. Faravelli, G. Bozzano, M. Dente, E. Ranzi, A kinetic modeling study of the thermal degradation of halogenated polymers, J. Anal. Appl. Pyrol. 72 (November (2)) (2004) 253-272.

[55] A.E.S. Green and S.M. Sadrameli, Analytical representations of experimental polyethylene pyrolysis yields, J. Anal. Appl. Pyrol. 72 (November (2)) (2004) 329-335.

[56] T. Faravelli, G. Bozzano, C. Scassa, M. Perego, S. Fabini, E. Ranzi, M. Dente, Gas product distribution from polyethylene Pyrolysis, J. Anal. Appl. Pyrol. 52 (September (1)) (1999) 87-103.

[57] E. Ranzi, M. Dente, T. Faravelli, G. Bozzano, S. Fabini, R. Nava, V. Cozzani, L. Tognotti, Kinetic Dimension of polyethylene and polypropylene thermal degradation, J. Anal. Appl. Pyrol. 40-41 (1997) 305-319.

[58] A. Nemeth, M. Blazso, P. Baranyai, T. Vidoczy, Thermal degradation of polyethylene modeled on tetracontane, J. Anal. Appl. Pyrol. 81 (2008) 237242. 
[59] T. Arii, S. Ichihara, H. Nakagawa, N. Fujii, A kinetic study of the thermal decomposition of polyesters by controlled-rate thermogravimetry, Thermochim. Acta 319 (1998) 139-149.

[60] T.M. Kruse, S.E. Levine, H.W. Wong, E. Duoss, A.H. Lebovitz, J.M. Torkelson, L.J. Broadbelt, Binary mixture pyrolysis of polypropylene and polystyrene: A modeling and experimental study, J. Anal. Appl. Pyrol. 73 (June (2)) (2005) 342-354.

[61] Y.C. Lu and K.K. Kuo, Thermal decomposition study of hydroxylterminated polybutadiene, HTPB, solid fuel, Thermochim. Acta 275 (1996) 181-191.

[62] C. Carmicino and A. Russo Sorge, Performance comparison between two different injector configurations in a hybrid rocket, Aerosp. Sci. Technol. 11 (2007) 61-67.

[63] C. Lee, Y. Na, J.-W. Lee, Y.-H. Byun, Effect of induced swirl flow on regression rate of hybrid rocket fuel by helical grain configuration, Aerosp. Sci. Technol. 11 (2007) 68-76.

[64] S.M. Reshetnikov and I.S. Reshetnikov, Oxidation kinetic of volatile polymer degradation products, Polym. Degrad. Stabil. 64 (1999) 379-385.

[65] Y. Nakamura, T. Kashiwagi, S.L.Olson, K. Nishizawa, O. Fujita, K. Ito, Two-sided ignition of a thin PMMA sheet in microgravity, P. Combust. Inst. 30 (2005) 2319-2325. 
[66] H. Gotoda, S.L. Manzello, Y. Saso, T. Kashiwagi, Effects of sample orientation on nonpiloted ignition of thin poly, methyl methacrylate, sheets by a laser 2. Experimental results, Combust. Flame 145 (2006) 820-835.

[67] M. Calabro, L.T. De Luca, L. Galfetti, H. Raina, C. Perut, Advanced Hybrid Solid Fuels, in: 58th International Aeronautical Congress, Hyderabad, India, paper $\mathrm{n}^{\circ} \mathrm{C} 4-2-09,2007$.

[68] L.T. DeLuca, L. Galfetti, F. Severini, L. Rossettin, L. Meda, G. Marra, B. D’Andrea, V. Weiser, M. Calabro, A.B. Vorozhtsov, A.A. Glazunov, G.J. Pavlovets, Physical and ballistic characterization of AlH3-based space propellants, Aerosp. Sci. Technol. 11 (2007) 18-25.

[69] B. Hidding, M. Pfitzner, D. Simone, C. Bruno, Review of the potential of silanes as rocket/scramjet fuels, Acta Astronaut. 63 (2008) 379-388.

[70] M.R. Weismiller, T.L. Connell, G.A. Risha, R.A. Yetter, Characterization of Ammonia Borane (NH3BH3) Enhancement to a Paraffin Fueled Hybrid Rocket System. in: 46th AIAA/ASME/SAE/ASEE Joint Propulsion Conference \& Exhibit, Nashville, Tennessee, July 25-28, 2010, AIAA 20106639.

[71] J.D. DeSain, T.J. Curtiss, K.M. Metzler, B.B, Brady, Testing Hypergolic Ignition of Paraffin Wax / LiAlH4 Mixtures, in: 46th AIAA/ASME/SAE/ASEE Joint Propulsion Conference \& Exhibit, Nashville, Tennessee, July 25-28, 2010, AIAA 2010-6636. 
[72] L. Courthéoux, D. Amariei, S. Rossignol, C. Kappenstein, Thermal and catalytic decomposition of HNF and HAN liquid ionic as propellants, Appl. Catal. B-Environ. 62 (2006) 217-225.

[73] B.M. Abu-Zied, Oxygen evolution over $\mathrm{Ag} / \mathrm{Fe}_{\mathrm{x}} \mathrm{Al}_{2-\mathrm{x}} \mathrm{O}_{3}, 0.0 \leq \mathrm{x} \leq 2.0$, catalysts via $\mathrm{N}_{2} \mathrm{O}$ and $\mathrm{H}_{2} \mathrm{O}_{2}$ decomposition, Appl. Catal. A-Gen. 334 (2008) $234-242$.

[74] N. Gascoin, P. Gillard, A. Mangeot, A. Navarro-Rodriguez, Detailed kinetic computations and experiments for the choice of a fuel-oxidiser couple for hybrid propulsion, J. Anal. Appl. Pyrol. Companion research paper under review.

[75] S. Rahimi, A. Peretz, B. Natan, On Shear Rheology of Gel Propellants, Propell. Explos. Pyrot. 32 (2) (2007) 165-174.

[76] R.N. Walters, S.M. Hackett, R.E. Lyon, Heats of Combustion of High Temperature Polymers, Federal Aviation Administration and Fire Safety, USA, Fire Research, DOT/FAA/AR-TN97/8, September 1998, www.fire.tc.faa.gov/pdf/chemlab/hoc.pdf, last accessed the 10/10/2011.

[77] A. Dessarthe, Introduction aux plastiques et composites en mécanique, Techniques de l'Ingénieur, August 1996, B5170

[78] Zs. Czégény, E. Jakab, A. Vig, B. Zelei, M. Blazso, Thermal decomposition of photooxidized isotactic polypropylene, J. Anal. Appl. Pyrol. 56 (November (2)) (2000) 229-242.

[79] HSC Chemistry, Chemistry Software, http://www.hsc-chemistry.net/, last accessed the 10/10/2011. 
[80] W. Kaminsky and J. Franck, Monomer recovery by pyrolysis of poly(methyl methacrylate) (PMMA), J. Anal. Appl. Pyrol. 19 (1991) 311-318.

[81] D.S. Achilias, Chemical recycling of poly(methyl methacrylate) by pyrolysis. Potential use of the liquid fraction as a raw material for the reproduction of the polymer, Eur. Polym. J. 43 (6) (2007) 2564-2575.

[82] T. Kashiwagi, A. Inabi, A. Hamins, Behavior of primary radicals during thermal degradation of poly(methyl methacrylate), Polym. Degrad. Stabil. 26 (2) (1989) 161-184. 


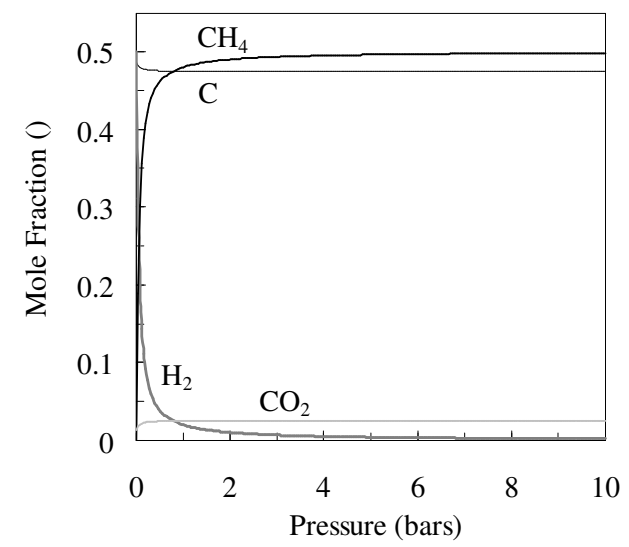

a)

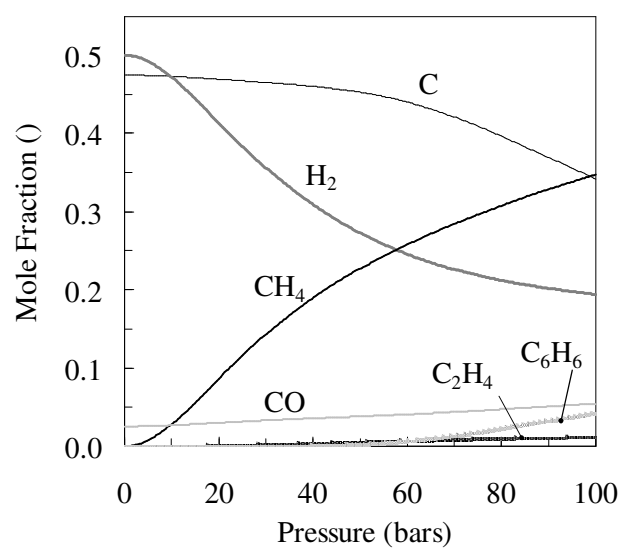

c)

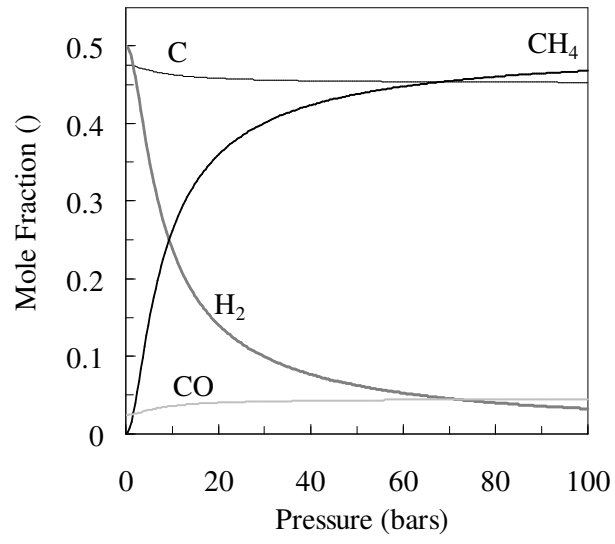

b)

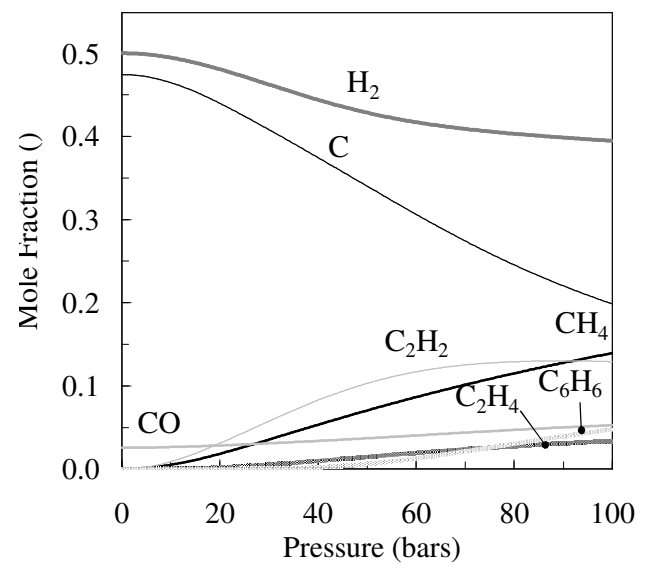

d)

Figure 1. Pressure effect on equilibrium product distribution for HTPB pyrolysis at: a) $500 \mathrm{~K}$, b) $1000 \mathrm{~K}$, c) $1500 \mathrm{~K}$, d) $2000 \mathrm{~K}$. 


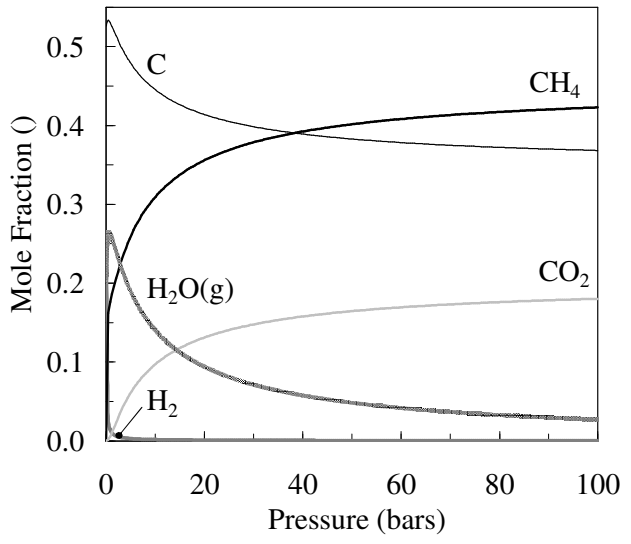

a)

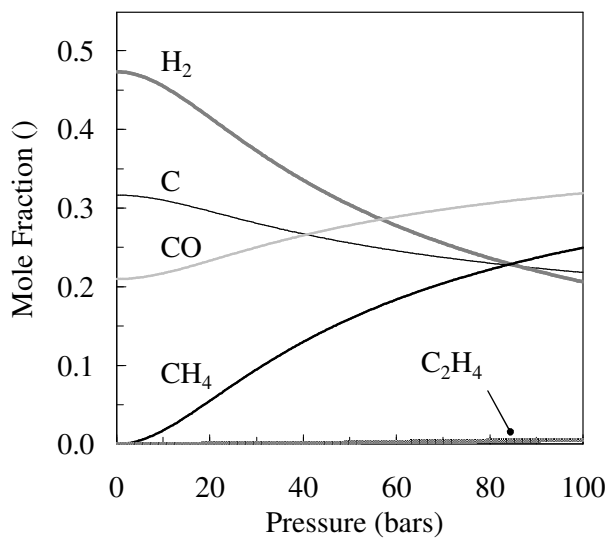

c)

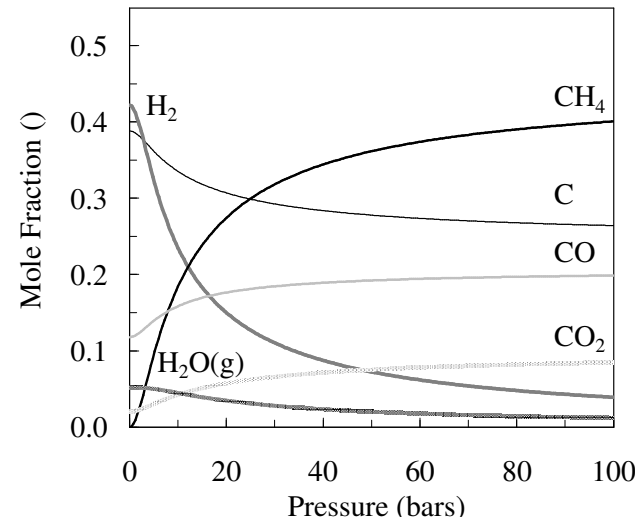

b)

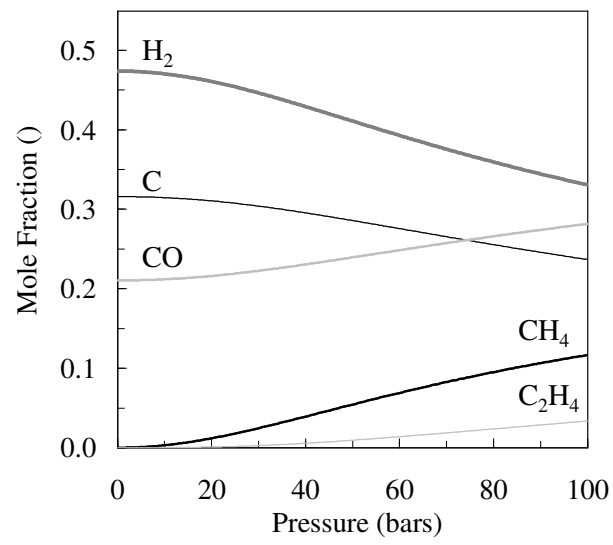

d)

Figure 2. Pressure effect on equilibrium product distribution for PMMA pyrolysis at: a) $500 \mathrm{~K}$, b) $1000 \mathrm{~K}$, c) $1500 \mathrm{~K}$, d) $2000 \mathrm{~K}$. 
Table 1. Arrhenius parameters for a one-step mechanism.

\begin{tabular}{ccccc}
\hline \hline & PMMA & HDPE & PP & HTPB \\
\hline Chemical Formula & $\left(\mathrm{C}_{5} \mathrm{O}_{2} \mathrm{H}_{8}\right)_{\mathrm{n}}$ & $\left(\mathrm{C}_{2} \mathrm{H}_{4}\right)_{\mathrm{n}}$ & $\left(\mathrm{C}_{3} \mathrm{H}_{6}\right)_{\mathrm{n}}$ & $\left(\mathrm{C}_{4} \mathrm{H}_{6}\right)_{\mathrm{n}}(\mathrm{OH})_{2}$ \\
\hline $\begin{array}{c}\text { Pre-Exponential } \\
\text { Factor }\left(\mathrm{s}^{-1}\right)\end{array}$ & $5.10^{3}-8.6 .10^{19}$ & $4.510^{28}$ & $3.1710^{24}$ & $1211-1.310^{11}$ \\
{$[19]$} & {$[23]$} & {$[23]$} & {$[16]$} \\
$\begin{array}{c}\text { Activation Energy } \\
\left(\mathrm{kJ} \mathrm{mol}^{-1}\right)\end{array}$ & $96.14-221.5$ & 445.2 & $222.3-373.4$ & $8.78-275.9$ \\
$\begin{array}{c}\text { Regression rate } \\
\left(\mathrm{mm} \mathrm{s}^{-1}\right) \text { at } 960 \mathrm{~K}\end{array}$ & {$[19]$} & {$[23]$} & {$[23]$} & {$[16]$} \\
\hline \hline
\end{tabular}


Table 2. Properties of polymers [67,76,77]

\begin{tabular}{|c|c|c|c|c|c|}
\hline & PMMA & HDPE & PP & $\mathrm{PC}$ & НТРВ \\
\hline Chemical Formula & $\left(\mathrm{C}_{5} \mathrm{O}_{2} \mathrm{H}_{8}\right)_{\mathrm{n}}$ & $\left(\mathrm{C}_{2} \mathrm{H}_{4}\right)_{\mathrm{n}}$ & $\left(\mathrm{C}_{3} \mathrm{H}_{6}\right)_{\mathrm{n}}$ & $\begin{array}{c}\left(\mathrm{C}_{6} \mathrm{H}_{4} \mathrm{O}-\right. \\
\mathrm{C} 3 \mathrm{H}_{6^{-}} \\
\left.\mathrm{C}_{6} \mathrm{H}_{4} \mathrm{CO}_{2}\right)_{n}\end{array}$ & $\left(\mathrm{C}_{4} \mathrm{H}_{6}\right)_{\mathrm{n}}(\mathrm{OH})_{2}$ \\
\hline Density $\left(\mathrm{kg} \cdot \mathrm{m}^{-3}\right)$ & 1190 & 960 & 950 & 1200 & 890 \\
\hline $\begin{array}{l}\text { Ambient Heat capacity } \\
\qquad\left(\mathrm{J} \mathrm{kg}^{-1} \mathrm{~K}^{-1}\right)\end{array}$ & 1420 & 1850 & 1900 & 1250 & 2900 \\
\hline $\begin{array}{l}\text { Thermal conductivity } \\
\left(\mathrm{W} \mathrm{m}^{-1} \mathrm{~K}^{-1}\right)\end{array}$ & 0.19 & 0.4 & 0.15 & 0.2 & 0.14 \\
\hline $\begin{array}{l}\text { Melting temperature } \\
(\mathrm{K})\end{array}$ & 450 & 415 & 420 & 500 & 420 \\
\hline $\begin{array}{c}\text { Absolute values of } \\
\text { heat release }\left(\mathrm{MJ} \mathrm{kg}^{-1}\right)\end{array}$ & 25 & 42 & 43 & 30 & 28.4 \\
\hline Young modulus (Gpa) & $1.8-3.1$ & 0.8 & $1.5-2$ & 2.6 & 0.0016 \\
\hline
\end{tabular}

